\title{
Hill Slope Failure During The Development Of Infrastructure Projects In Himalaya: Case Study of Udhampur- Ramban National Highway, Jammu and Kashmir, India
}

\author{
Fallos en los taludes de las colinas durante el desarrollo de proyectos de \\ infraestructura en el Himalaya: Estudio de caso de la carretera nacional \\ Udhampur-Ramban, Jammu y Cachemira, India
}

DOI: $10.46932 / \mathrm{sfjdv2n5-101}$

Received in: Oct 1st, 2021

Accepted in: Dec 30th, 2021

\author{
Vinay Kumar Pandey \\ D. Sc. Ph. D \\ Geosystems Infrastructures, Mumbai, India. \\ E-mail:vinay78pandey@gmail.com
}

\begin{abstract}
Himalaya is youngest tectonic Active Mountain and northern boundary of India. Various infrastructure projects are under develop in Himalayan region for the better connectivity of peoples and national security of border line. Widening of $295 \mathrm{~km}$ National Highway-44 in Jammu and Kashmir is an important developmental project. The highway passes through Outer Himalayan and Higher Himalayan sequences of rocks and is frequently affected by landslides at various places. The paper deals with $43 \mathrm{~km}$ UdhampurChenani and Nashri- Ramban section of the highway within sedimentary and metamorphic rock sequence. The area is prone to landslides on account of fragile geological, topographic and hydrological conditions. The study area has high rainfall intensity and numerous old landslides zones. During the project feasibility stage, project authority has identified the landslide prone area and suggested precautionary measures but during the construction work various unpredicted landslide and ground sinking events happened which given trouble in project construction cost and project completion time. In this paper, the challenges faced due to landslide and ground failure as failure of old slide adjutant to road construction, agriculture and residential ground failure at higher altitude due to road construction, collapse of high tension towers in cut slopes; its impact on construction activities; are discussed with mitigation measures for unidentified landslide related challenges.
\end{abstract}

Keywords: Landslide, Geological and hydrological factors, Colluvium deposits, Angle of Repose, Mitigation measures.

\section{RESUMEN}

El Himalaya es la montaña tectónica activa más joven y la frontera norte de la India. En la región del Himalaya se están desarrollando varios proyectos de infraestructuras para mejorar la conectividad de los pueblos y la seguridad nacional de la línea fronteriza. La ampliación de los $295 \mathrm{~km}$ de la carretera nacional 44 en Jammu y Cachemira es un importante proyecto de desarrollo. La autopista atraviesa secuencias rocosas del Himalaya exterior y del Himalaya superior y se ve afectada con frecuencia por desprendimientos de tierra en varios lugares. El artículo trata de los $43 \mathrm{~km}$ de la sección UdhampurChenani y Nashri- Ramban de la autopista dentro de la secuencia de rocas sedimentarias y metamórficas. La zona es propensa a los desprendimientos debido a las frágiles condiciones geológicas, topográficas e hidrológicas. El área de estudio tiene una alta intensidad de lluvias y numerosas zonas de deslizamientos 
antiguos. Durante la fase de viabilidad del proyecto, las autoridades identificaron la zona propensa a los corrimientos de tierra y sugirieron medidas de precaución, pero durante las obras de construcción se produjeron varios corrimientos de tierra y hundimientos imprevistos que causaron problemas en el coste de construcción y en el plazo de ejecución del proyecto. En este artículo, se discuten los desafíos que se enfrentan debido a los deslizamientos de tierra y fallas en el suelo como el fracaso de la antigua diapositiva adyacente a la construcción de la carretera, la agricultura y la falla del suelo residencial a mayor altura debido a la construcción de carreteras, el colapso de las torres de alta tensión en las laderas de corte; su impacto en las actividades de construcción; con medidas de mitigación para los desafíos relacionados con los deslizamientos de tierra no identificados.

Palabras clave: Deslizamiento de tierra, factores geológicos e hidrológicos, depósitos de coluvión, ángulo de reposo, medidas de mitigación.

\section{INTRODUCTION}

Jammu and Kashmir ( J\&K) is northern most state of India and 90\% of geographical area falling under Himalayan range. J\&K state is very important in view of political, defence, tourism and spiritual purpose. Jammu to Srinagar National Highway-44 (NH-44; earlier NH-1A) is only one connecting road to Kashmir valley and Leh-Ladakh region. Jammu-Srinagar national highway NH-44 is life line for everyone. This road is passing through Outer Himalaya to Higher Himalayan range with very complex and landslide prone area. NH-44 is frequently closed during rainy season, which cutoff Kashmir valley to remaining India. For smooth connectivity, road widening work is under progress.

Study area, Udhampur- Chenani and Nashri- Ramban road section (road chainage from Km 67+000 to $\mathrm{Km} 89+000$ and $\mathrm{Km} \mathrm{130+000} \mathrm{to} \mathrm{Km} \mathrm{151+000)} \mathrm{considering} \mathrm{critical} \mathrm{geological} \mathrm{risks} \mathrm{due} \mathrm{to} \mathrm{hill}$ slope failure. The project location has shown below as figure 1 .

Topographically area has highly variation; road elevation varies from 327 mean sea level (msl) to $2400 \mathrm{msl}$ (Jammu to Patnitop). The road stretch from Udhampur to Ramban is tectonically very sensitive and is prone to heavy and recurrent land slides during rain fall season, the chances of failure increases drastically. These slides not only pose problems during execution of work but also add to the problems of traffic management. 
Figure-1: The project corridor is schematically presented in an Index Map.

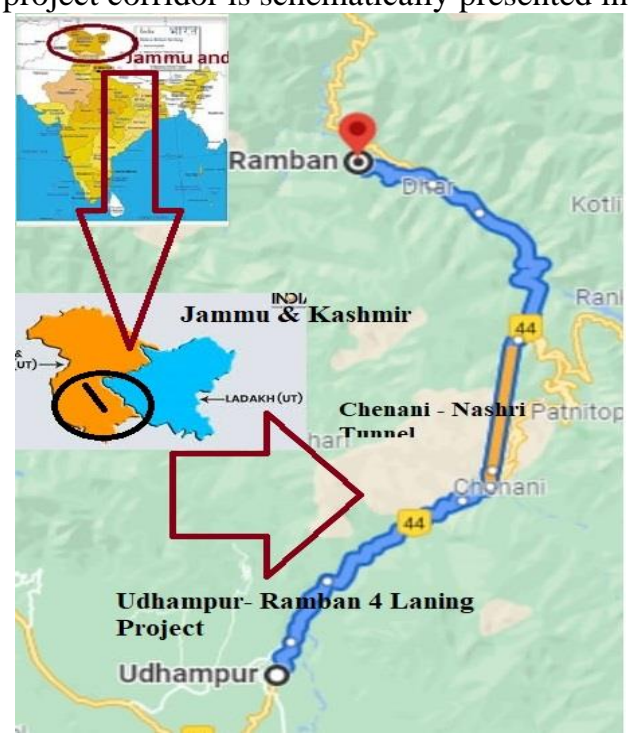

The road passes through unstable hill strata over the Shivaliks, Pir Panjal and sub-Himalayas. The altitude on this road varies from 500 - 600 Mtrs. The climatic changes play a major role in disintegration of hill slopes. The temperature during summer ranges between $10^{\circ}$ to $42^{\circ}$. In winters, the temperature goes down to (-) 10 degree Centigrade at night and 15 to 20 degree Centigrade during day time. Heavy rains with cloud burst are common features of this region. Sometimes, rains upto $200 \mathrm{~mm} /$ day have been recorded. Cloud bursts are frequent and devastating.

The Geomorphology of the road section is characterized by moderate to steep valleys. Presence of narrow river valley and numerous small perpendicular tributaries, mild to steep hill slopes and colluvium deposits at the toe of the slopes, are the main geomorphologic features of the project area. The slopes on both sides of river valley are varying generally from $30^{\circ}$ to $70^{\circ}$. The geomorphology of area seems highly erosion prone due to presence of weathered rock mass on the slopes, loose rock blocks, old landslide debris and rock slide debris deposits all along the slopes. The major valleys being longitudinal and are aligned in WNW-ESE direction.

Geologically, study area belongs to Outer Himalayan range, consisting of Murree formation. Lithologically, these sediments constitute semi-consolidated to consolidated sandstones, siltstone, mudstone, shales, conglomerates and clay beds. Structurally these rocks display broad anticlines and synclines. A series of thrust is a characteristic tectonic feature in nearby study area. The most prominent among them are Main Boundary Fault (MBF) from the Outer Himalayan strata.

The rock formations present at the north end from MBF/ Murree fault onwards consists of quartzite/phyllitic quartzite/phyllites interbedded with thin slate/phyllites bands and partings. The various phyllitic quartzite bands are light grey to white coloured and very in thickness from $60-100 \mathrm{~cm}$, though bands of smaller thickness are not uncommon. During the reconnaissance of the site this have been 
observed that different geological discontinuities such as shear zones, slip planes, joints and foliation shear zones have undergone shearing movements. Even though the order of movement may be small (10$20 \mathrm{~cm}$ ), it has developed broken character in the rocks, created continuity and interconnection of geological features. The former reflects effects on load bearing characteristics of foundations rocks and the latter the seepage conditions of the foundations media.

Earthquake history, micro seismicity and the presence of longitudinal and transverse thrust faults in the region, it is concluded that the study area is quite vulnerable to earthquakes. The Jammu and Kashmir partial comes under Seismic Zone IV and partial in zone V.

As per approved design and provided ROW (Right to Work), civil team had started the hill excavation but due to poor geology; faced various slope and ground failure which disturbed the unidentified problems such as collapse and cracks in residential building, agriculture land, high tension electricity tower and usual identified landslide. Civil Team had faced losses in form of man power, machineries, precious project time and project cost. Challenges due to unidentified landslide/ ground failure issue have been discussed in this paper with probable causes and mitigation measures, which will beneficial in other project also and government bodies should take care in upcoming project for saving the project time and project cost.

\section{LANDSLIDE ZONES ALONG HIGHWAY}

Landslide along the NH-44 is normal phenomena. Several old landslide zones have observed along the existing highway. Landslide is the result of a wide variety of processes, combination of one or more factors which include geological, geomorphological, geotechnical, hydro-meteorological factors such as rainfall and snow; and the reduction of shear parameter due to an increase of pore water pressure by saturation during spells of torrential precipitation and undercutting/toe erosion by water bodies. Rock falls occur along closely spaced and steeply dipping joints, while planar and wedge failures occur due to the intersection of adversely-oriented joint planes. Slides on the thick colluvium deposits have also observed. Colluvium deposit had made up of cobbles, boulders and Silty sand and clay sand soil which increase the chances of liquefaction in presence of water. Main landslide areas are Bali landslide, Samroli landslide and Narsoo landslide which were observed by various researchers such as Bhat et.al.(2002), Chingkhei et.al.(2013),'Pandey(2018), Singh (2006), slope stability report(2016), Verma(1966)

\subsection{MAJOR LANDSLIDES ALONG THE HIGHWAY ALIGNMENT}

The road stretch from Udhampur to Ramban is tectonically very sensitive and is prone to heavy and recurrent land slides during rain fall season/snow fall, the chances of failure increases drastically. The district of Udhampur is located in the Shivalik range of Himalayas and the terrain is gentle slope 
mountainous. The upper reaches of the district experience snowfall in the winter season. Soft rock such as Mud stone, clay stone, siltstone with alternate band of sandstone is well exposed, with many small water bodies, Nallas and Major River is Tawi. Hills are covered with vegetation and due to water intrusion along joints and reaction with soft rocks; area becomes prone to landslide, ground shrinking and mud/debris flow along the slopes. Causes of landslides in studied area are divided into three factors, discussed below:

Geological and topographical factors: Geologically area is made up of weak rocks with four to six sets of joints and covered with overburden materials consist of boulders and soil. Slope angle $\left(45^{\circ}\right.$ to $\left.70^{\circ}\right)$, alternate bands of weak rocks and valley side natural slope have increases the frequency of landslide.

Hydrological factors: As area is made up of loose overburden material with weak rock and unfavorable joint orientation, nominal rainfall causes the erosion/sludge flow and as rainfall varies 600$900 \mathrm{~mm}$ annually with twice in a year; water percolated in between the joints and causes liquefaction, which is one of the causes of landslide in this area. Frequency of Cloud burst event in higher ridges is increasing and causes the flash flood and brings boulders and sludge and blocks the road.

Human and construction activities: For fulfill the daily basis needs, local public had made the agriculture land after cutting the natural vegetation as well as diverted the water for irrigation and drinking purpose through small drains. During diversion of water, water percolated underneath the soil which causes the slope failure in some area. Excavation along the road or in loose strata, disturbed the natural slope.

Several sizeable landslides can be observed along the present as well as the proposed new alignment. The main causative factors of these landslides are fragility of the geological and geomorphic setting; climatic factors such as rains and snow; and the reduction of shear parameters due to an increase of pore water pressure by saturation during spells of torrential precipitation and undercutting/toe erosion by rivers/streams. Rock falls occur along closely spaced and steeply dipping joints, while planar and wedge failures occur due to the intersection of adversely-oriented joint planes. Slides on the thick colluvium deposits have been observed, mostly in the section before $\mathrm{Km} \mathrm{145.} \mathrm{The} \mathrm{type} \mathrm{of} \mathrm{slide} \mathrm{material}$ and thickness varies according to the type of mother rock. The weak and highly erosion prone layers of Mudstone/Siltstone/ Shale in between the Sandstone layers, which are comparatively strong, generally control the slides in the Murree series. In other formations, slides are governed by the joint plane bedding, plane characteristics. The present section comprises sizeable slides such as Balli (KM 71), KM 76, Samroli Slide (KM 79), Narsoo (KM 82), Nashri Slide (Km 132), Dhalwas Slide (KM 133-135),Peerah Slide (Km 136), Chanderkot (KM 137) and Duggi Pulli (KM 142), Neera Slide (Km 145), Cafeteria Mod (KM 147). 
As a contribution towards the mitigation process, a study has been carried out along the highway to analyses kinematic stability and qualitative estimation of rock mass condition through rock mass classifications. The kinematic analysis shows that the rock slopes are prone to debris flow, rock fall, rotational, circular, wedge and planar failure.

Rock falls occur along closely spaced and steeply dipping joints, while planar and wedge failures occur due to the intersection of adversely-oriented joint planes. Slides on the thick colluvium deposits have also observed. Colluvium deposit had made up of cobbles, boulders and Silty sand and clay sand soil which increase the chances of liquefaction in presence of water.

\subsection{GEOLOGICAL \& GEOTECHNICAL ASSESSMENTS OF MAJOR LANDSLIDES}

The geological and geotechnical assessment were carried out by taking the traverses along hill and valley side of existing highway of all the major slides during site visit. The emphasis has been laid on geological, morphological and climatic conditions and other engineering properties for geotechnical assessments of slope instability. The relevant photographs of landslide were collected for the geotechnical assessments.

A brief description of major slides along the alignment is being presented below (Table-1):

Table-1: Showing location of recent landslides

\begin{tabular}{|c|c|c|c|c|c|}
\hline S. No. & \multicolumn{2}{|c|}{$\begin{array}{l}\text { Location } \\
\text { Chainage }(\mathrm{km})\end{array}$} & $\begin{array}{l}\text { Name of } \\
\text { Landslides }\end{array}$ & Failure pattern & Descriptions \\
\hline 1 & $68+100$ & $68+150$ & & $\begin{array}{l}\text { Debris flow and } \\
\text { Rotational failure }\end{array}$ & $\begin{array}{l}\text { Highly weathered mudstone } \\
\text { with alternate band of sandstone } \\
\text { covered with colluvium material } \\
\text { with water charged seasonally. }\end{array}$ \\
\hline 2 & $68+500$ & $68+600$ & Bali Slide & $\begin{array}{l}\text { Debris flow and } \\
\text { Rotational failure }\end{array}$ & $\begin{array}{l}\text { Old Landslide area. Highly } \\
\text { weathered mudstone with } \\
\text { alternate band of sandstone } \\
\text { covered with colluvium material } \\
\text { with water charged seasonally. }\end{array}$ \\
\hline 3 & $68+800$ & $68+900$ & Bali Slide & $\begin{array}{l}\text { Debris flow, } \\
\text { Rotational failure }\end{array}$ & $\begin{array}{l}\text { Old Landslide area. Area is } \\
\text { covered with colluvium } \\
\text { material. Road is collapsed due } \\
\text { to shrinking of colluvium mass. }\end{array}$ \\
\hline 4 & $70+400$ & $70+475$ & & Rock fall & $\begin{array}{l}\text { Highly weathered and jointed } \\
\text { mudstone with alternate band of } \\
\text { sandstone covered with water } \\
\text { charged seasonally }\end{array}$ \\
\hline 5 & $74+100$ & $74+175$ & & $\begin{array}{l}\text { Debris fall and } \\
\text { Toe movement }\end{array}$ & $\begin{array}{l}\text { Highly weathered and jointed } \\
\text { mudstone with alternate band of } \\
\text { sandstone covered with } \\
\text { colluvium mass and water } \\
\text { charged. }\end{array}$ \\
\hline 6 & $75+600$ & $76+100$ & Samroli Slide & $\begin{array}{l}\text { Rotational failure } \\
\text { and debris fall }\end{array}$ & $\begin{array}{l}\text { Old Landslide area highly } \\
\text { weathered, sheared and crushed } \\
\text { rock mass of mudstone with } \\
\text { sandstone with water charged }\end{array}$ \\
\hline
\end{tabular}




\begin{tabular}{|c|c|c|c|c|c|}
\hline 7 & $78+100$ & $78+300$ & & $\begin{array}{l}\text { Planner failure, } \\
\text { rock fall and } \\
\text { debris fall }\end{array}$ & $\begin{array}{l}\text { Moderately weathered } \\
\text { sandstone with alternate band of } \\
\text { mudstone with thin silty sand } \\
\text { soil. Dipping towards valley } \\
\text { side about } 45^{\circ}-60^{\circ}\end{array}$ \\
\hline 8 & $78+900$ & $79+100$ & & $\begin{array}{l}\text { Rotational failure } \\
\text { and debris fall }\end{array}$ & $\begin{array}{l}\text { Highly weathered mudstone } \\
\text { with alternate band of sandstone } \\
\text { covered with colluvium material } \\
\text { with water charged seasonally. }\end{array}$ \\
\hline 9 & $80+350$ & $80+450$ & & $\begin{array}{l}\text { Rotational failure } \\
\text { and debris fall }\end{array}$ & $\begin{array}{l}\text { Area is covered with colluvium } \\
\text { material with water charged } \\
\text { seasonally. }\end{array}$ \\
\hline 10 & $82+900$ & $83+100$ & & $\begin{array}{l}\text { Rotational failure } \\
\text { and debris fall }\end{array}$ & $\begin{array}{l}\text { Area is covered with colluvium } \\
\text { material with water charged } \\
\text { seasonally. }\end{array}$ \\
\hline 11 & $84+800$ & $84+850$ & Chenani slide & $\begin{array}{l}\text { Rotational failure } \\
\text { and debris fall }\end{array}$ & $\begin{array}{l}\text { Old landslide. Area is covered } \\
\text { with colluvium material with } \\
\text { water charged seasonally. }\end{array}$ \\
\hline 12 & $86+020$ & $86+100$ & Chenani slide & $\begin{array}{l}\text { Rotational failure } \\
\text { and debris fall }\end{array}$ & $\begin{array}{l}\text { Old landslide. Area is covered } \\
\text { with colluvium material with } \\
\text { water charged seasonally. }\end{array}$ \\
\hline 13 & $130+600$ & $130+700$ & & $\begin{array}{l}\text { Rotational failure } \\
\text { and debris fall and } \\
\text { toe failure }\end{array}$ & $\begin{array}{l}\text { Area is covered with colluvium } \\
\text { material with water charged } \\
\text { seasonally. Road is shrinking. }\end{array}$ \\
\hline 14 & $131+200$ & $131+700$ & Nashri Slide & $\begin{array}{l}\text { Rotational failure } \\
\text { and debris fall }\end{array}$ & $\begin{array}{l}\text { Old landslide. Area is covered } \\
\text { with colluvium material with } \\
\text { water charged seasonally. Road } \\
\text { is shrinking. }\end{array}$ \\
\hline 15 & $132+740$ & $133+240$ & $\begin{array}{l}\text { Dalwash } \\
\text { Slide }\end{array}$ & $\begin{array}{l}\text { Rotational failure } \\
\text { and debris fall }\end{array}$ & $\begin{array}{l}\text { Area is covered with colluvium } \\
\text { material with water charged } \\
\text { seasonally. }\end{array}$ \\
\hline 16 & $135+200$ & $135+600$ & Pira Slide & $\begin{array}{l}\text { Rock fall and } \\
\text { Debris fall }\end{array}$ & $\begin{array}{l}\text { Highly weathered and jointed } \\
\text { mudstone with alternate band of } \\
\text { sandstone covered. }\end{array}$ \\
\hline 17 & $143+140$ & $143+200$ & Slide & $\begin{array}{l}\text { Rock fall and } \\
\text { debris fall }\end{array}$ & $\begin{array}{l}\text { Area is covered with Slaty } \\
\text { phyllitic quartzite and debris }\end{array}$ \\
\hline 18 & $\begin{array}{l}145+300 \\
(\mathrm{SB})\end{array}$ & $145+450(\mathrm{SB})$ & Neera Slide & $\begin{array}{l}\text { Rock fall and } \\
\text { debris fall }\end{array}$ & $\begin{array}{l}\text { Highly jointed and crushed } \\
\text { Slaty phyllitic quartzite with } \\
\text { steep slope. }\end{array}$ \\
\hline 19 & $\begin{array}{l}147+930 \\
(\mathrm{SB})\end{array}$ & $148+580(\mathrm{SB})$ & $\begin{array}{l}\text { Cafeteria } \\
\text { Slide (New } \\
\text { Slide) }\end{array}$ & $\begin{array}{l}\text { Rotational failure } \\
\text { and debris fall }\end{array}$ & $\begin{array}{l}\text { Highly jointed and crushed } \\
\text { Slaty phyllitic quartzite with } \\
\text { steep slope area. }\end{array}$ \\
\hline
\end{tabular}

\section{DISCUSSIONS}

During the Detailed project investigation (DPR) stage, old landslide zones have been identified and provided the protection work such as Breast wall, Retaining wall, Concrete Cladding and others. Minor soil failures were taking care but some slide zone were activated due to natural slope failure, geological and hydrological factors. In the Udhampur- Chenani road section, various slope/ground failure issues have been faced during construction activities which were not identified earlier. Due to sudden ground and slope failure, happened in the form of activated old landslide zone, damages of houses, agriculture and forest land, high tension tower collapse or in critical condition. Due to these unpredicted 
sudden ground failures events adversely impacted the project. Mainly three patterns of failures are observed:

I. Failure of active old slides adjutant to road construction

II. Agriculture and residential ground failure due to road construction at higher altitude

III.Collapse of High tension towers above the cut slopes

\section{Failure of active old slides adjutant to road construction}

Ch. $68+900 \mathrm{~km}$ to Ch. $69+300 \mathrm{~km}$, Ch. $75+600 \mathrm{~km}$ to Ch. $76+400 \mathrm{~km}$ and Ch. $84+500 \mathrm{~km}$ to Ch. $84+700 \mathrm{~km}$ are covered with thick colluvium material. Geologically synclinal structure Mudstone, Claystone and Silt stone are evidently. At above locations, namely Bali, Samroli, Chenani, Nashri, Peera and Neera landslides respectively have occurred in recent past.

These areas show the wedge and planner failures due to an increase of pore water pressure and sometime undercutting/toe erosion by rivers/water bodies which are activated during rainy season. Following landslide failures have been faced by Civil Team:

I a) Bali Landslide zone: Bali landslide zone is made up of colluvium material with $12-18 \%$ water content, $25-41 \%$ liquid limit, $17-20 \%$ plastic limit, having Slity sand (SM) in nature. These sliding activated during the monsoon, due to liquefaction. In this section minor bridge was proposed to avoid the landslide disturbance. CIVIL TEAM has permanently deputed the machineries for 3-4 months in monsoon season. Google earth image (fig 2) shows steep topography and colluvium materials in this landslide zone.

Figure 2: Google earth Image of Bali Slide

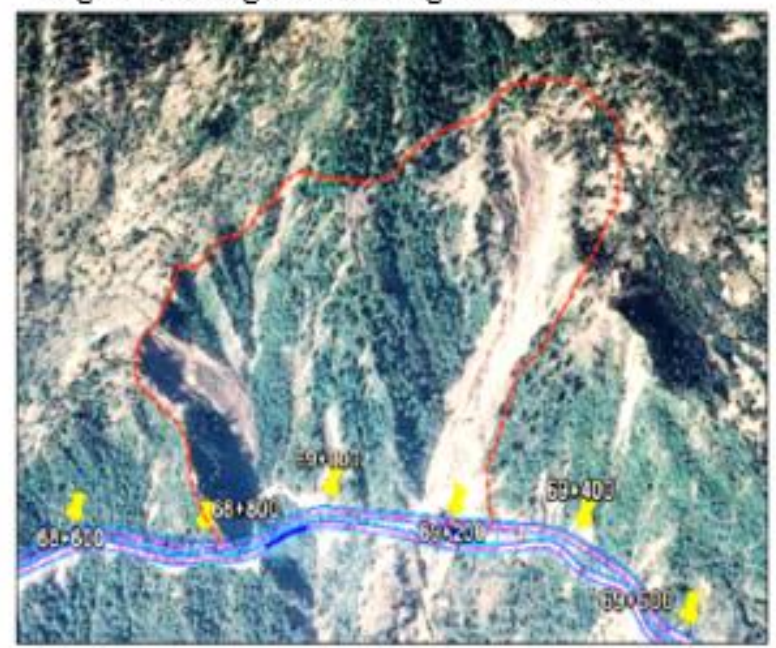

Figure 3: Google Earth Image of Samroli Slide

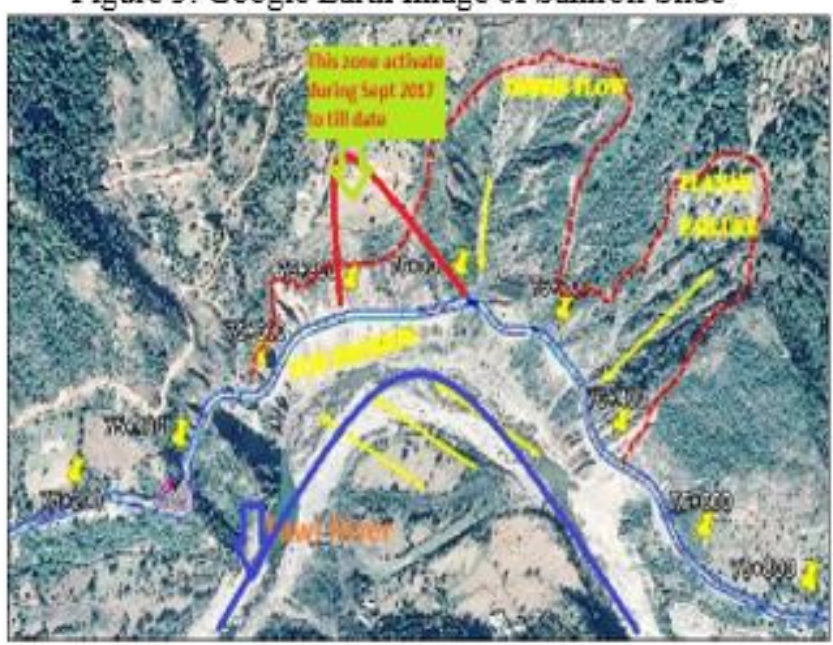

I. b) Samroli Landslide zone: This slide is in between Ch. $75+600 \mathrm{~km}$ to $\mathrm{Ch}$. $76+400$, differential and aggressive erosion of the Mudstone/shale layer in between the Sandstone layers. Soil properties are same as the Bali landslide zone. Anticline and Syncline geological feature are well developed in between the Sandstones and Mudstone layer. The crested part of this syncline is dislocated along right limb by a 
dip-slip fault and along left limb by a tear fault. The Sandstone bands are fractured and blocky in nature and due to the joint orientation, a series of triangular troughs of erosion have been created in the weaker rock. During rainy season the strata is water charged and lubricated along the joint planes and wedge failure and toe erosion beneath the Sandstone band; shown Samroli slide (fig 3).

The bridge abutment in this location was constructed in the month of August 2017 but in same year in month of September, sliding started and completely blocked the NH -44 for one week. Bridge was also covered with sliding mass, about $200 \mathrm{~m}$ long and 70-80m high. More cracks were observed about 60$70 \mathrm{~m}$ away from the top of slide area (photo 1). The cracks width was 20-30 cm, 50-60 m long and depth upto 4-5 $\mathrm{m}$ and beyond (photo 2 and 3). Cracks were developed in two high tension electricity tower foundation and agriculture land at the top of landslide. Minor bridge abutment was cracked and settled due to this slide, which completely blocked the NH-44 for single lane also (Photo 4). The Cracks were filled with Kanker, Sand, Cement aggregate. Drainage were also provided to avoid the surface water percolation inside the cracks.

I. c) Chenani Landslide Zone: Chenani landslide zone has colluvium material with $12-18 \%$ water content, 25-41\% liquid limit, 17-20\% plastic limit, having Slity sand (SM) in nature above rock. This area is about $150 \mathrm{~m}$ wide along the existing road level. It is largely a combination of slump and flow of surface material. The slide material is composed of mainly rock fragments in a matrix of brownish gray Silty sand. The maximum thickness of the colluvium is more than 10-20 $\mathrm{m}$. The existing road had been affected by the slide several times. This slide was activated during the monsoon, due to abrupt floods.

Photo 1: Samroli Landslide with dimension and cracks marked, during Sept 2017 event.

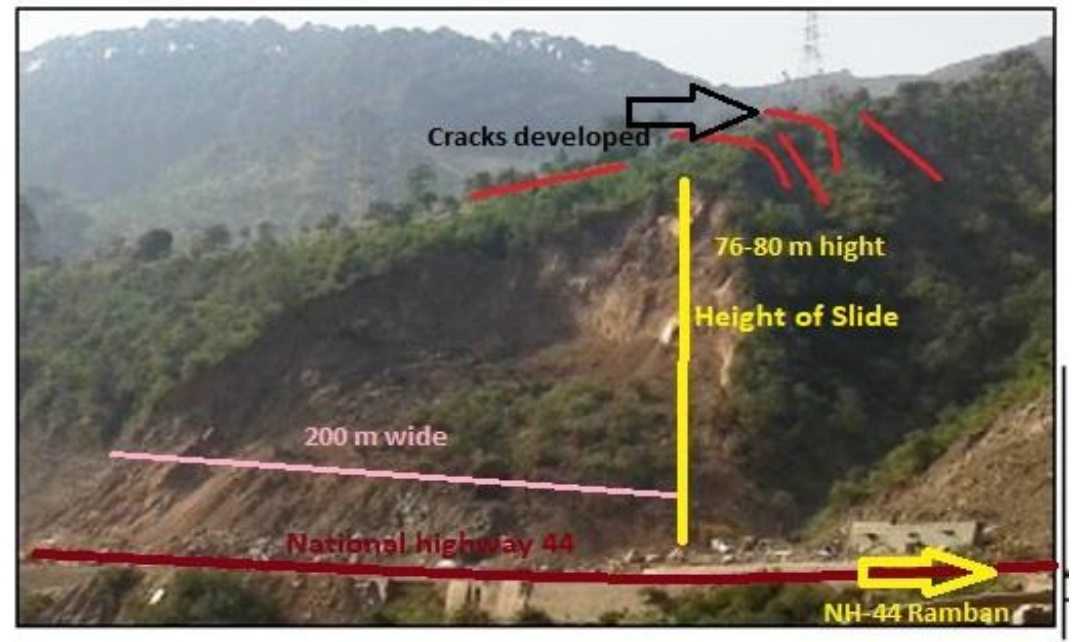


Photo 2 and 3: Cracks developed at top of Samroli Slide during September 2017 event.
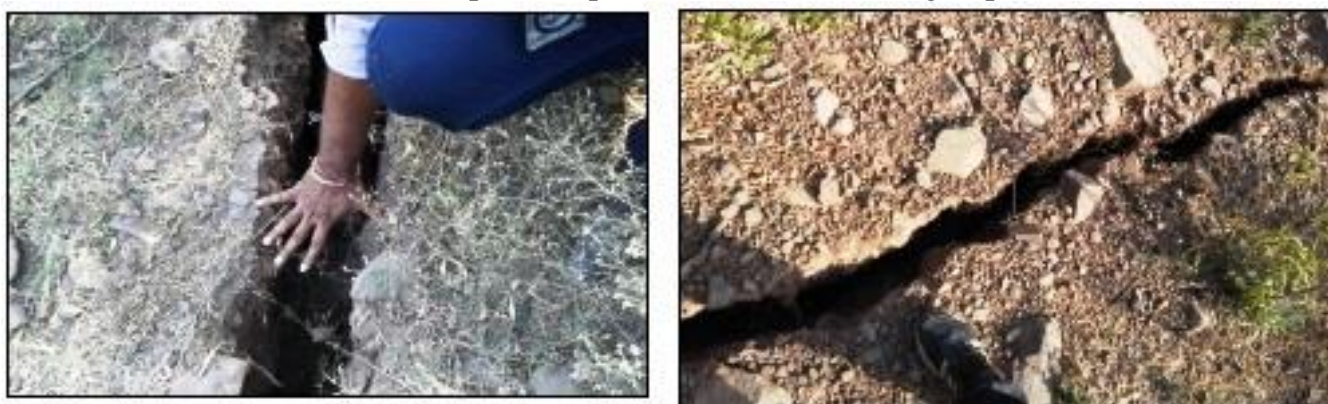

Photo 4: Settlement of bridge and Cracks in bridge abutment A2.

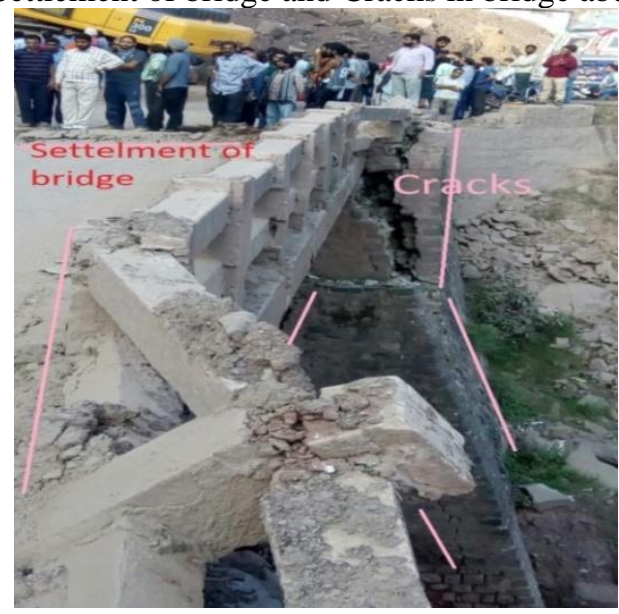

1 d) Nashri Slide at Ch km 130+600 to Km 130+700 and Km 131+200 to Km 131+700

Nashri is an old active landslide and is the most complex landslide on the NH-44 highway. Due to continuous sliding at Nashri location and blockage of National Highway-44, government had prepared 18 $\mathrm{km}$ new bypass road connecting Pira village to Battot in year 1966. But this slide is continuing activated and blocked NH time to time. The rocks on the northern end of the slide are highly folded and steeply dipping as it is closed to Murree, while those on the slide scar face and the road level on the southern side of the slide dip at gentle angle in SW direction. Selective erosion along the fault zone with consequent formation of a gully and large accumulation of debris pile /colluvium in this depression may have formed the base for the Nashri landslide. The prime cause of failure may be attributed to poor shear characteristics of the clays which further deteriorate on saturation, build up pore pressure and toe-erosion by the Nashri nala, about $120 \mathrm{~m}$ towards valley side.

At $\mathrm{Ch} \mathrm{km} \mathrm{130+600} \mathrm{to} \mathrm{Km} \mathrm{130+700,} \mathrm{slide} \mathrm{over} \mathrm{a} \mathrm{thick} \mathrm{colluviums} \mathrm{deposit} \mathrm{and} \mathrm{is} \mathrm{about} 100 \mathrm{~m}$ wide along the existing road level. It is largely a combination of slump and flow of surface material. The slide material is composed of mainly rock fragments in a matrix of brownish gray silty sand and some clay.

The existing road had been affected by the slide several times and road shrinked and collapsed. This is mostly originating when abrupt floods of water during heavy rain undermine and incorporate ample sediment and mobilization from landslides predominates. Civil team had tried many slope protection 
measures (Breast wall, Cladding wall, Micro Piling, Gabion wall) to stablize this area but due to deep insitu intect foundation and Rotational and debris fall, unable to protect this section.

Road shrinking at Ch Km 131+ 600 to km 131+700 was observed during on Sept 24, 2017; civil team representatives had observed the major movement along this slide. Cracks have been developed along the slope and road shrined \& bulked in form of 'Zig- Zag'. Refer photo no .5-6. For demarked the insitu rock, geological cross section were prepared by civil team Geologist based on rock exposed and dip direction and it was observed that bed rock is more than $200 \mathrm{~m}$ deep. Geological cross section has shown as figure 10.

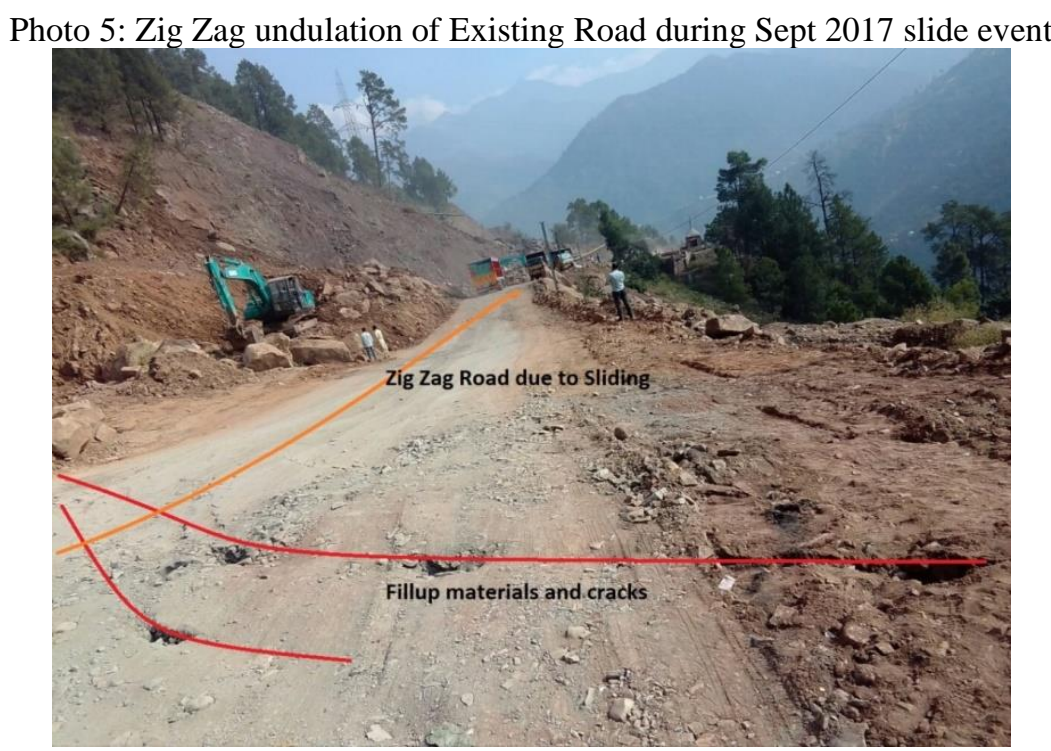

Photo 6: Zig Zag undulation of Existing Road during Sept 2017 slide event

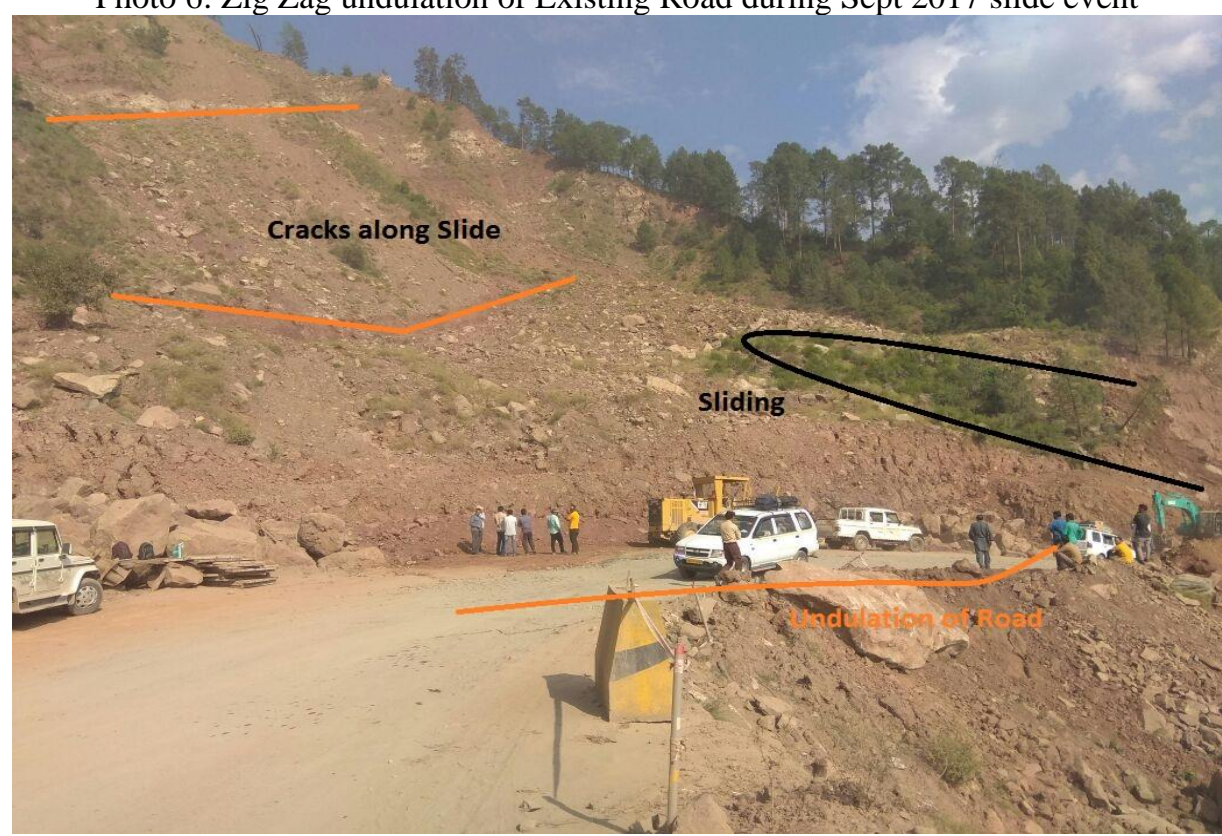


1 e) Pira Slide Ch Km 135+200 to Km 135+600

This slide is of the planar gliding type and extends for a length of around 50 to $100 \mathrm{~m}$. Structurally, the rocks dipping into the hill at an angle of $65^{\circ}$ towards SW. The Toe of the slope is eroded by Pira Nala. Through the dip slope is stable but due to highly jointed and weathered rock and increased the chances of rockfall. The rock is closely jointed, probably due to the tight folding, and its proximity to the thrust. The close jointed has also reduced the competency of the rock to stand on steep slopes and hence overhanging faces of the rock slide down on the road along with the debris at the higher levels. Site photographs are shown as below photo no 7 .

Photo 7: Pira Slide activated due to Proposed road alignment.

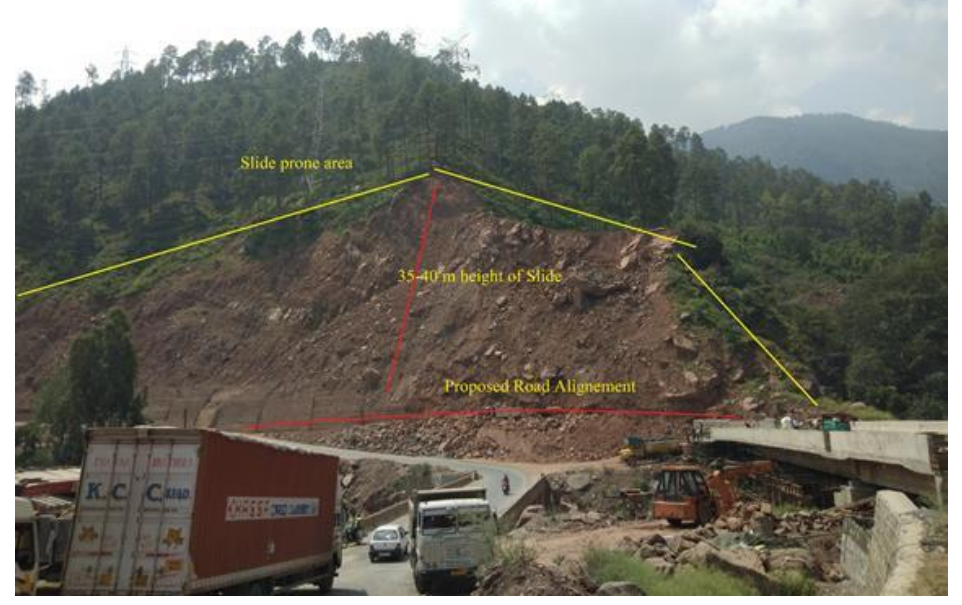

\section{1 f) Neera Slide Ch Km $145+300$ to Km $145+450$}

This slide zone is an old slide and on the right bank of the River Chenab. Practically the entire reach start from the river bridge over Chenab up to Ramban needs attention. In the stretch of the road, the slide is of the rock-fall type in talus and the slide is of the debris-flow type. A thick mantle of talus and scree covers the rock, which has been cut with steeper angle up to the proposed ROW. This fissure has apparently been caused by the sliding of the scree and is potential plane for future sliding of the screen.

The rock types underlying the scree comprise thinly bedded slates and phyllites interbedded with grey quartzites. The rock above the river bed, dip into the hill whereas at the river bed and on the left bank of the river, they dip in the opposite direction. Hence, and anticline fold with one limb dipping at 40-50 towards $\mathrm{N} 40^{\circ} \mathrm{E}$ and the other limb dipping at $80^{\circ}$ to $85^{\circ}$ towards $\mathrm{S} 40^{\circ} \mathrm{W}$ has been inferred.

The rock is closely jointed, probably due to the tight folding, and its proximity to the thrust. The close jointed has also reduced the competency of the rock to stand on steep slopes and hence overhanging faces of the rock slide down on the road along with the debris at the higher levels. 
This slide happened every year several times and blocked the traffic about one week continuously during the winter rainfall. During the year 2017, slide was reactivated due to road widening work and major challenge for widening the road in this section. Slope angle is more than $70^{\circ}$ with fragile rock. Presently, top of slide is about $120 \mathrm{~m}$ height from NH 44 but cracks are far beyond the 200-300m. civil team had taken precautionary measures for stabiles the slide but every measures are good for nothing. Slide photo is attached as photo no 8 .

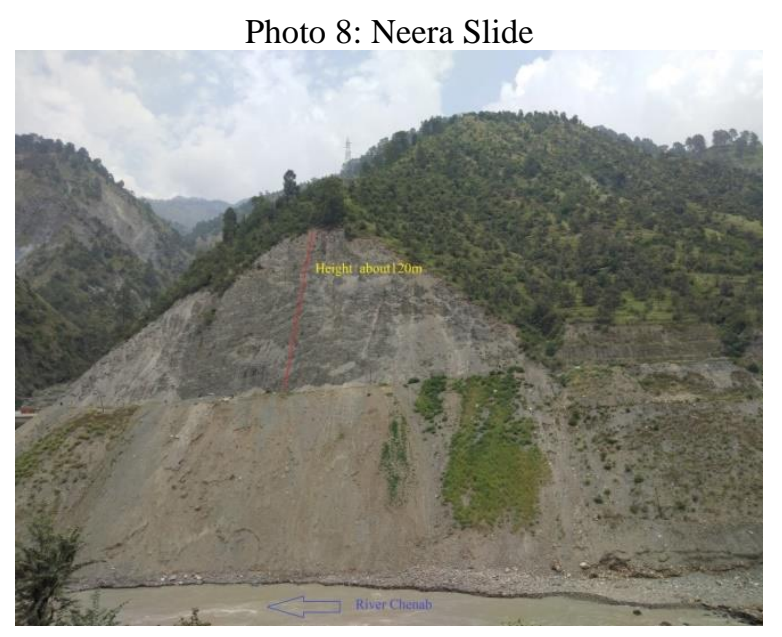

1 g) Ramban Slide Ch km 147+930 to Km 148+580

The rock type exposed along the road section from $\mathrm{Km} \mathrm{147+930} \mathrm{to} \mathrm{Km} \mathrm{148+580} \mathrm{are} \mathrm{slate} \mathrm{and}$ phyllite with alternate band of grey to dark grey quartzite, which shows multiple shearing, highly fracture, moderately to highly weathered, slightly rough to rough surface and damp to wet ground water condition. The estimated RQD value along this section is less than 15 estimated UCS value is less than $20 \mathrm{MPa}$. The estimated rock mass condition along hill slope is poor and Slope mass rating of hill slope is Class V which indicate unstable. The probable failure expected along hill slope is wedge and toppling failure with $60 \%$ possibility of slope failure and debris flow in case of saturated condition. This landslide has triggered at regular interval throughout the year especially during rain fall along the hill slope of $\mathrm{NH}-44$. More than $650 \mathrm{~m}$ to $200 \mathrm{~m}$ length of the road section has been severely affected due to landslide and slope failure. Deep seated failure has not been observed but it is a large and very frequent slide. Refer site photo 9- 10. Height of slide from NH-44 is more than $150 \mathrm{~m}$. Most critical section at near the cafeteria, Ramban town, where whole hill mass has fallen down and many casualties happened. 
Photo 9: Ramban Slide Ch Km 147+930 to Km 148+580

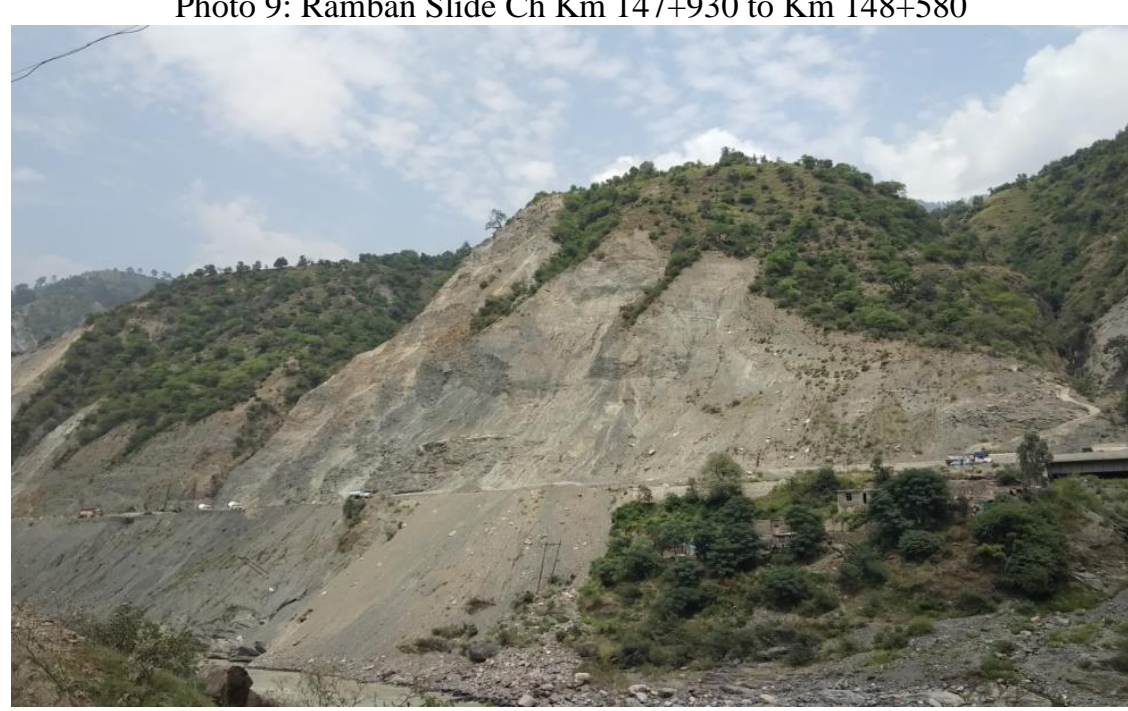

Photo 10: Ramban Cafeteria Slide Ch Km 147+930 to Km 148+580

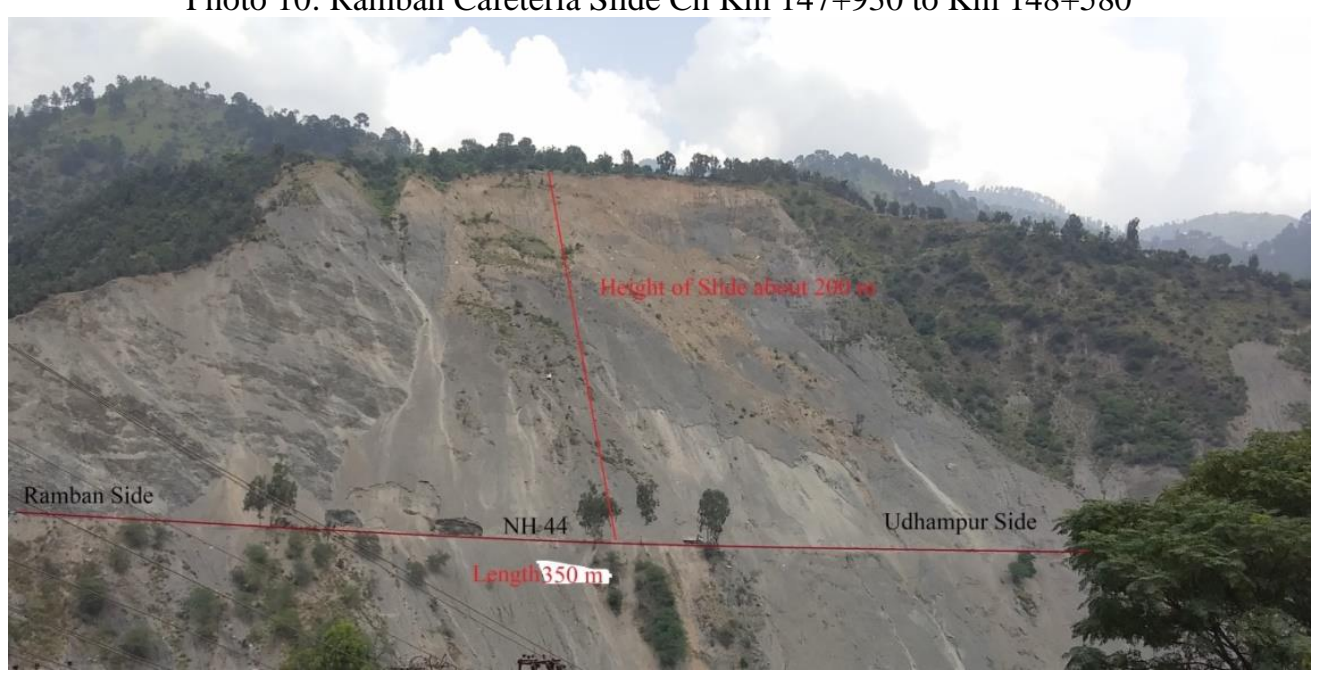

\section{Agriculture and residential ground failure due to road construction at higher altitude}

Along the hill top the houses and agriculture land were developed. Due to thick cover of colluvium and debris material as well as poor strength rock and toe erosion, several areas near the slide zone, grounds started sinking at Bali village (Ch $70 \mathrm{~km}$ to $\mathrm{Ch} 73 \mathrm{~km}$ ), Toldi village (near Ch $78 \mathrm{~km}$ ) and Narsoo village (Ch $81 \mathrm{~km}$ to $82 \mathrm{~km}$ ), were affected:

II. a) Bali Village: Maximum numbers of houses damage were reported in this area. Geologically area is made up of thick colluvium materials- Silty soil with big boulders, slope are gentle with medium cover of vegetation. Google Earth image is showing that areas forming spoon shape (Landslide prone area) due to hydrological and man-made activities in this area. Rock present at deep level and slope angle are also high. Geomorphological, hydrological and geologically area have landslide favorable zone and old landslide zone. Presence of water, good agricultural soil had attracted humans for settlement in this 
area. Strength of colluvium materials would be very less and due to water percolation in subsurface lubrication form at contact plane of rock and colluvium, landslide has been started at huge level.

II. b) Toldi Village: Only one number of house damage was reported in this area. House is very near the ROW of project. Geologically area is made of thin colluvium materials 3-4 m before the Siltstone interbedded with sandstone rock, dipping gentle towards valley side.

II. c) Narsoo Village: Three number of house damage complains were reported in this area. Houses are about $150 \mathrm{~m}$ far from the ROW provided to civil team. Geologically area is made of thick colluvium materials (3-4 m) and Siltstone interbedded with sandstone rock, dipping gentle towards valley side. Rock present at shallow depth and slope angle is high with valley side and increasing the probability of landslide.

\section{Collapse of high tension towers above the cut slopes}

High tension electricity tower at Ch $71+300 \mathrm{~km}$ passing near the ROW were suddenly collapsed in afternoon (60 m away from ROW) due to ground sinking at Bali slide zone. Study based on geological strata and slope failure prediction and importance of issues, identified 28 numbers of towers in critical condition in which 26 numbers were suggested to be protected by micro piles, rock anchors and cladding wall as per site condition and 2 towers suggested shifting. Another tower (32.70m from ROW) at same chainage was also collapsed within one month of collapsing of first tower. Some tower photographs are given below (Photo 11-12):
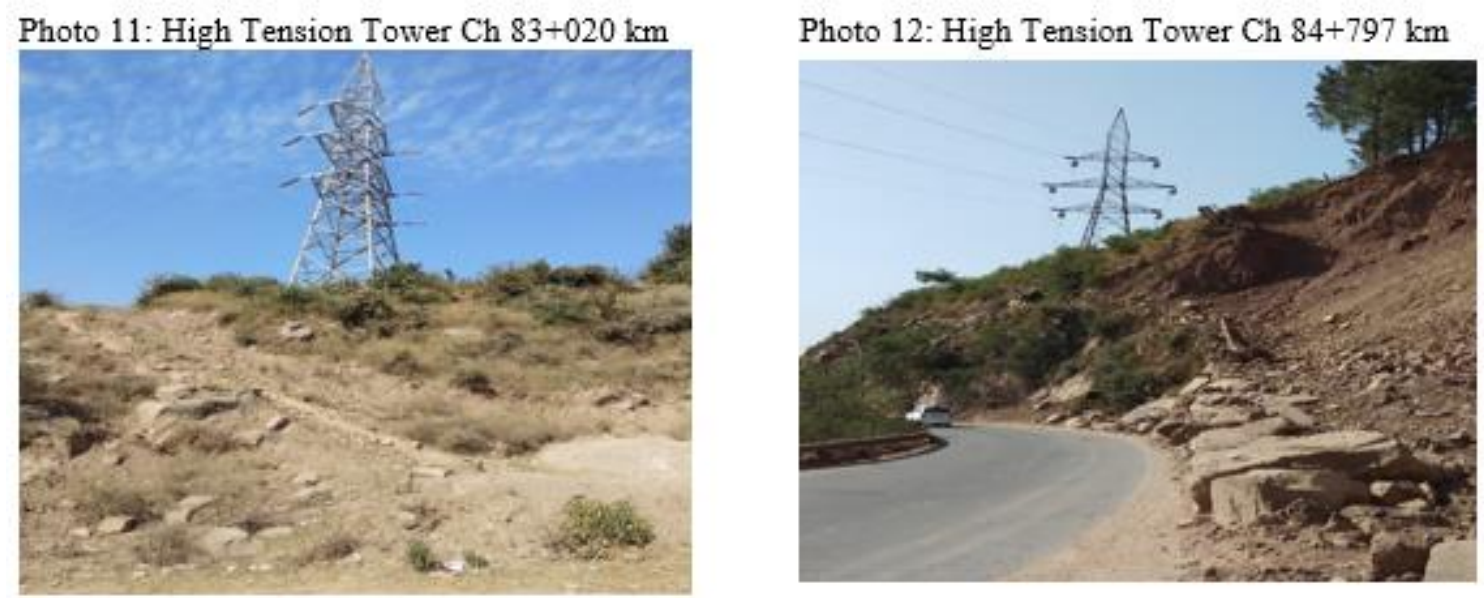

\subsection{Causes for landslide highway}

We have observed the mechanical causes for land sliding for both the section, given below:

I. As rock is rich with clay content in Murree formation which easily loss its pore water pressure during contact with water and landslide happens. Causes may be considered to be factors that made the slope vulnerable to failure, that predispose the slope to becoming unstable. The trigger is the single event that finally initiated the landslide. Thus, causes combine to make a slope vulnerable to failure, and the trigger finally initiates the movement. 
Geological conditions and external factor mainly include the structure of rock and soil masses, lithology, terrain, tectonic structure, hydrogeological conditions and ground stress, etc., i.e. the basic material conditions; presence of clay in joints, rain fall and snow plays an important role. Furthermore, external triggering factors chiefly include the slope dead weight, rainfall, temperature change, external load, slope excavation for North bound carriageway etc., that provide the external dynamic conditions for slides in Murree formation..

II. After crossing the Murree thrust at Pira Village Dogra slate and phyllite with alternate band of grey to dark grey quartzite which shows multiple shearing, highly fracture, moderately to highly weathered, slightly rough to rough surface with steep slope hills are present and water condition along joints are damp to wet. The probable failure expected along hill slope is wedge and toppling failure, slope failure and debris flow in case of saturated condition. This landslide has triggered at regular interval throughout the year especially during rain fall along the hill slope of NH-44. Geological condition at Dogra slate (Pira village to Chenab river bridge) rock is dipping towards valley side and after crossing Chemab bridge dipping inside the hill. The rock is closely jointed, probably due to the tight folding, and its proximity to the thrust. This area is situated under high tectonical stress between the Murree and Digdol thrust and minor active faults. The close jointed has also reduced the competency of the rock to stand on steep slopes and hence overhanging faces of the rock slide down on the road along with the debris at the higher levels. The rock mass fails during monsoon seasons due to decrease in shear strength parameters of rock mass while pore water pressure increased such as saturated condition.

Apart from the above discussed mechanical reason for landslide, wants to highlight the natural caused of landslide that is angle of repose of hill slope, which varies material to material. Along the entire section, geological strata are same but few locations having landslide apart from geological factors. Old landslides were also naturally stabilized because slope has maintained its own angle of repose. Steep angle hill slope to be protected with modern engineering applications but we observed that human engineering would not be $100 \%$ suitable for all the project section. As we felt at $\mathrm{Ch} \mathrm{km} 84+720$, where both support systems (Micro piling and cladding wall) were collapsed due to sliding mass.

There are several cases worldwide where slope failure due to hill cutting with taking all the precautionary measures happened worldwide and its indicated that we have to find out some other natural way to stabiles the hill slope. Ashok K Singh et al (2018), Fang Wei (2019) and Vinay et al (2021) have discussed in detail about slope failure and role of angle of repose in slope stabilization. It was also discussed about zone wise Himalayan angle of repose such as in outer Himalaya that is $20^{\circ}-45^{\circ}$ as it made up of various sedimentary rock (sandstone, Lime stone and mudstone/ claystone), Lesser or Middle Himalayas having $30^{\circ}-75^{\circ}$ due to made up of low-grade, Metasedimentary rocks, Metavolcanic strata and augen gneiss. The Greater Himalaya is $45^{\circ}-65^{\circ}$ and made up of granite and gneisses overlain by metamorphosed sediments schist and Tethyan Himalaya is $30^{\circ}-60^{\circ}$ and made up of sandstone, shale and limestone. He also highlighted the slope failure cases worldwide, given below:

One best example for failure of slope protection measure is at South and North portal of Chenani- Nashri tunnel (situated in between the Chenani and Nashri on same alignment), where 
authorities had applied major slope protection measures but hill slope protection measures are damaged several times apart from slope south portal road is also shrinking due to toe erosion. Refer photo no 13-14. Fang Wei (2019) has described the slope failure due after taking the all slope protection precautions in Taizaifu Area, Fukuoka, China. Slope failure at Fukuoka, China has shown in figure no 4.

Ashok K Singh et al (2018) has studied the slope failure along the National Highway (NH)-5 in Jhakri region of Himachal Pradesh, India draws frequent concern due to heavy damage and traffic disruption almost every year, after the detailed studied and find that a high vulnerable slope due to steep slope angle. Refer photo 15.

Photo 13: Slope Protection failure at South Portal of Chenani- Nashri Tunnel, J\&K, India

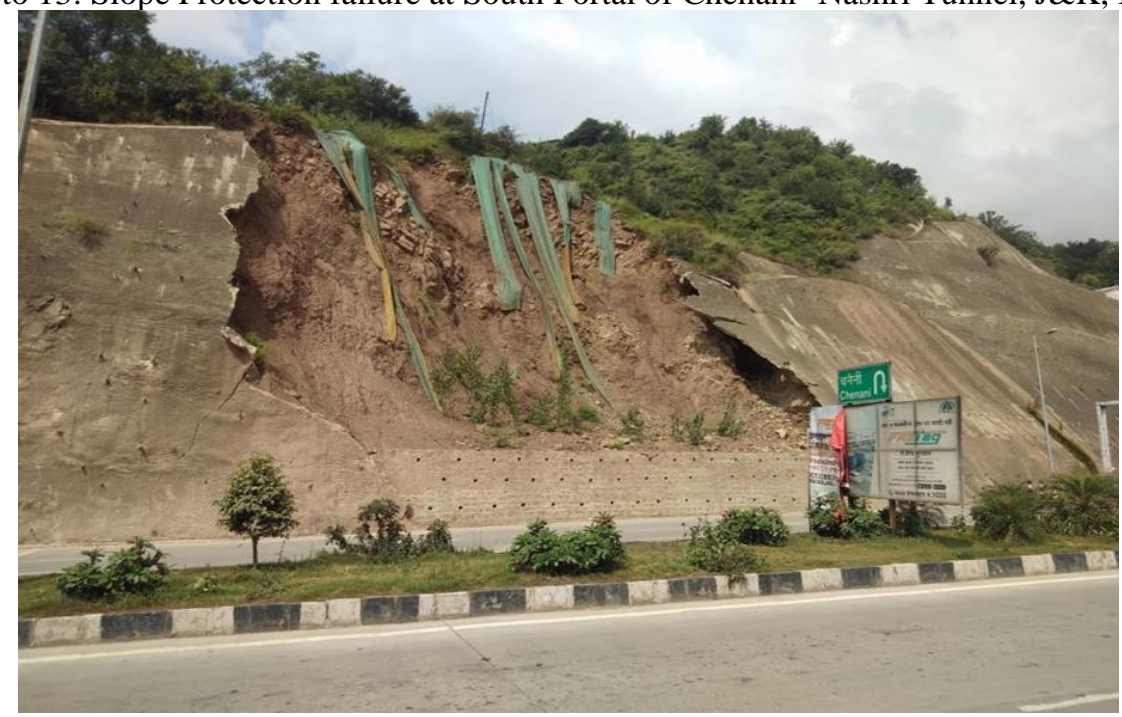

Photo 14: Slope Protection failure at South Portal of Chenani- Nashri Tunnel, J\&K, India

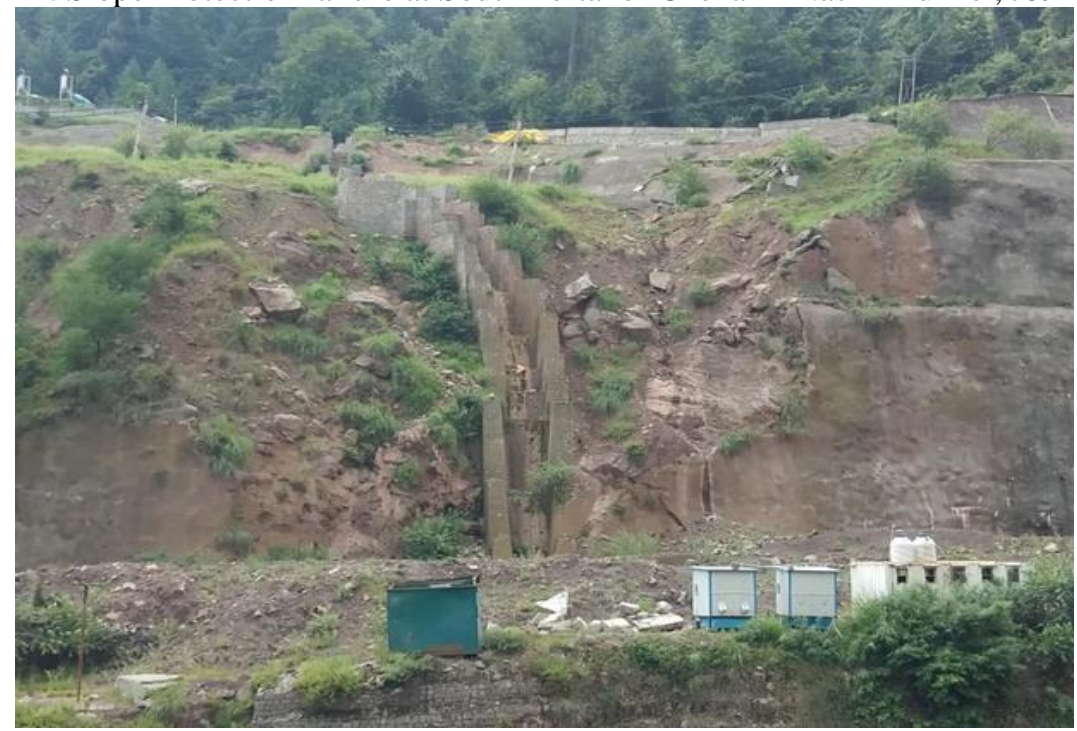


Figure 4: Slope Failure after the hill cutting and slope precautionary measures in Fukuoka, China (Fang Wei, 2019)

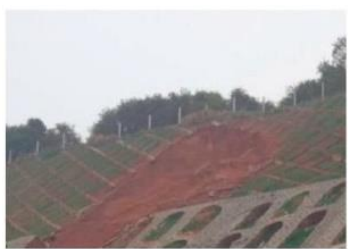

Slope Failure after taking slope precautionarv measures

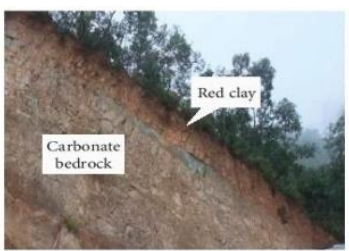

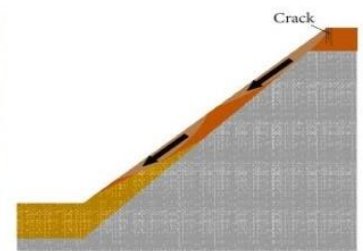

$\begin{array}{ll}\text { - Sliding mass } & \text { - Soft layer } \\ \text { - Rigid layer } & \text { - Bedrock }\end{array}$

(c)

Integral sliding along the stratum interface.
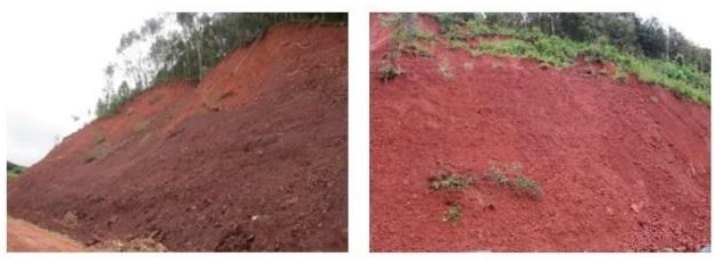

(b)

Planar sliding under rainfall.

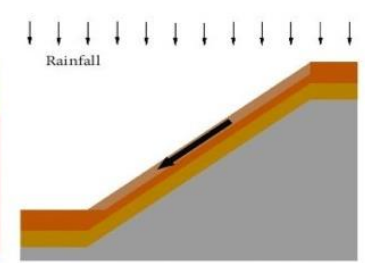

Sliding mass $=$ Soft layer

Photo 15: Slope failure due to step angle hill cutting at NH -05 Jhakri, Himachal Pradesh

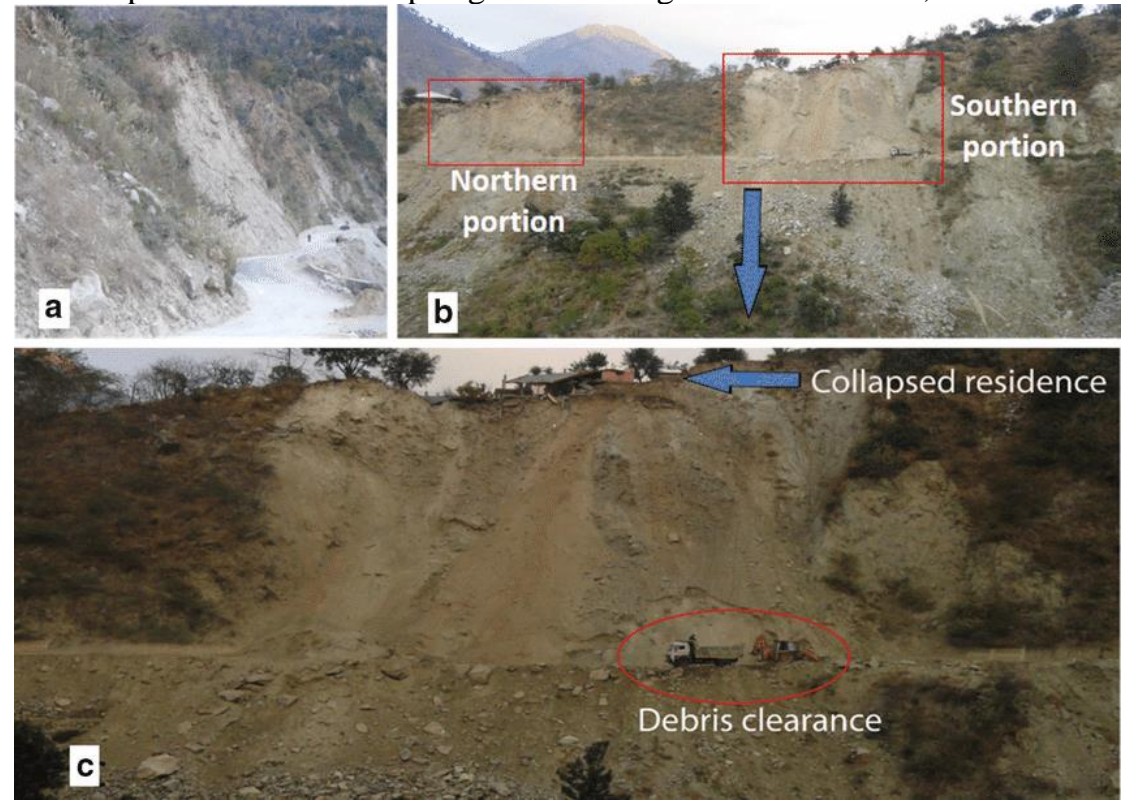

One conceptual plan is shown in figure no 5, considering the hill slope respect to hill cut. Hill natural slope is $44^{\circ}$, hill cut width is $14 \mathrm{~m}$, excavated hill slope is $77^{\circ}$ and protected with modern engineering methods as rock bolt/anchors with breast wall, wire mess and other precautionary measures. Applied slope protection measures are sufficient respect to hill cutting but may not be viable respect to large scale hill slope failure. One gentle angle hill cut has shown along the road are more stable for large scale hill slope failure. Definitely more land required for maintaining the hill slope but we can avoid the probability for the future land mass movement. 
Figure 5: Conceptual plan for gentle hill cutting

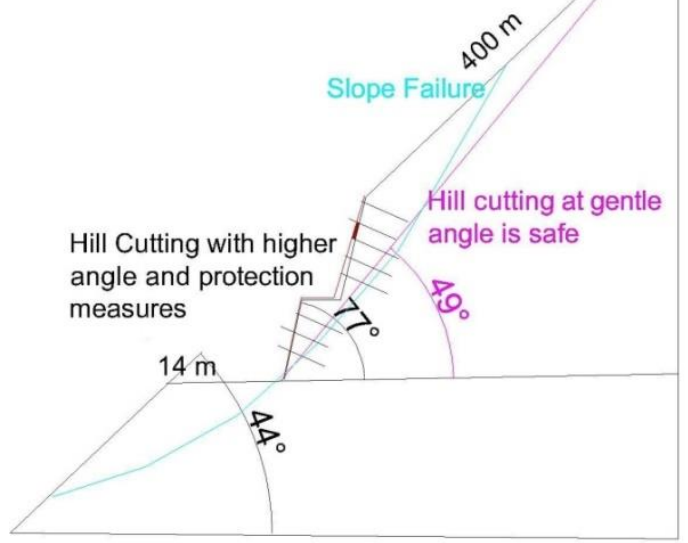

For the Udhampur -Ramban four lanning of project, hill slope topography and geology is highly variable and provided ROW in general way 21-40 m from the center of the road median. Designer and civil team have tried to maintain the hill slope within the provided ROW but there were some locations were natural angle of repose cannot be maintained. At some location soil/rock mass movement were started at 100-200 $\mathrm{m}$ far from ROW and very difficult to protect the area. That mass load/pressure was as much high that even Concrete Retaining wall, $140 \mathrm{~mm}$ diameter micro piling (1/3 length of total length of micro pile intact under insitu rock) unable to hold the load.

For Murree formation as discussed earlier, natural hill slope is $35^{\circ}-45^{\circ}$ and for Salkhala formation natural hill slope is $45^{\circ}-60^{\circ}$. As per provided ROW, design team had proposed the hill slope at an angle of $70^{\circ}-75^{\circ}$, which is not sufficient as per angle of repose/original hill slope stabilization and accordingly mentioned required hill slope for naturally stable the slope at an angle of $45^{\circ}-60^{\circ}$. Refer figure no $5 \& 6$ below.

Figure 5: Conceptual Hill Slope comparison shown along the project under Murree formation.

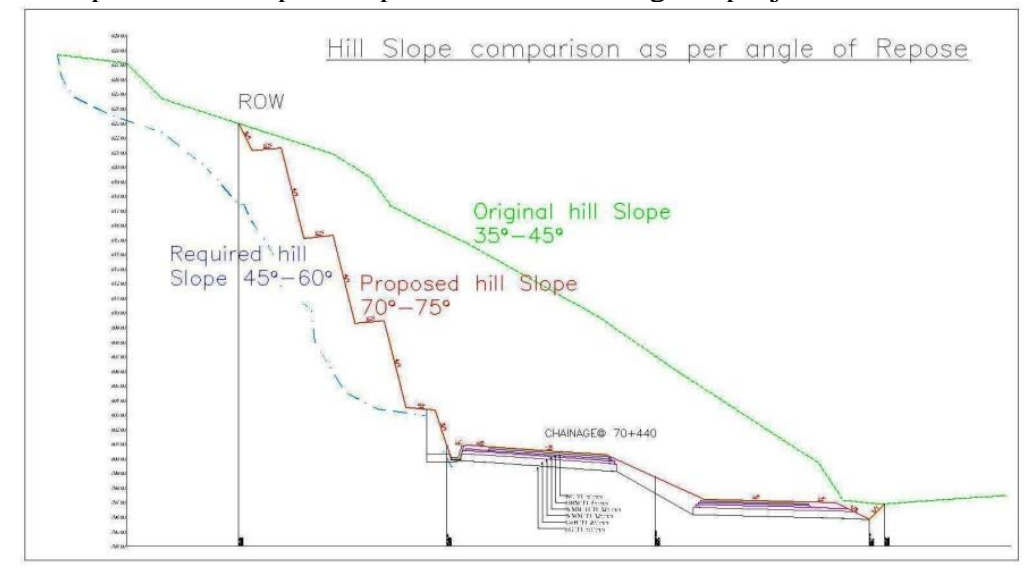


Figure 6: Conceptual Hill Slope comparison shown along the project under Salkhala formation

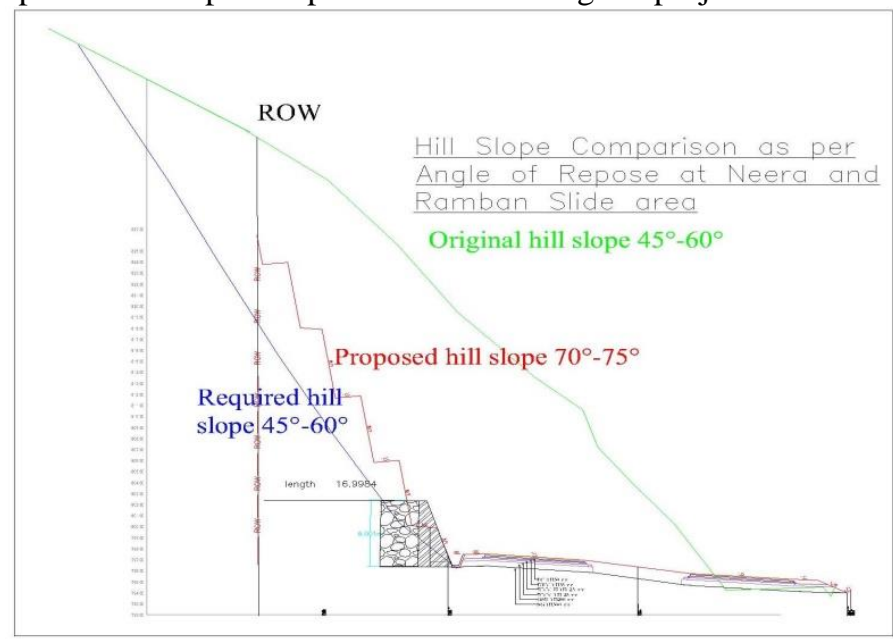

\section{CONCLUSION}

Udhampur -Ramban four laning of project is very crucial project in view of J\&K, Ladhak connectivity as well as national security. Area is full of geological and geotechnical challenges. There are some old landslides and some generated due to high angle hill slope. Landslide during the monsoon season becomes terrified. After the site visit and detailed study, it is observed that limitation of acquired land for maintaining the natural hill slope according to geology and topography of particular area.

Nature has its own engineering process and much perfect than modern engineering. Angle of repose plays important role in natural slope stability. For protection of hill slope we have to maintain sufficient slope angle depends on rock type and geological factors. Slope protection for small area in hilly terrain depends on bedding, joint orientation, ground water flow, vegetation and angle of repose. We have many examples that slope protection is good for nothing if angle of repose is not maintain during hill cutting. It is suggested to be acquired sufficient land for maintains the natural angle of repose (min $45^{\circ}$ for outer Himalaya and $60^{\circ}$ for Middle Himalaya) by the authorities. Less land acquisition is cheaper during initial stage of project but challenges faced during the construction and operational stage of project become much higher. Modern engineering have to understand the hidden cost of landslide and maintenance cost with respect to time and take early steps regarding angle of repose in developing infrastructure projects in Hill area. 


\section{REFERENCES}

Bhat G.M., Pandita, S.K., Dhar, B.L., Sahni, A.K. and Haq, Ihsan-Ul (2002). Preliminary Geotechnical Investigation of Slope Failures along Jammu-Srinagar National Highway between Batote and Banihal. Reprinted from Aspects of Geology Environment of the Himalaya, 275-288. http://www.scirp.org/(S(351jmbntvnsjt1aadkposzje))/reference/ References Papers.aspx?ReferenceID=1417557. Accessed 10 Nov 2019.

Chingkhei R. K., Shiroyleima A, Robert L, Singh and Kumar A (2013). Landslide Hazard Zonation in NH-1A in Kashmir Himayala, India. International Journal of Geosciences. 4. pp 1501-1508. http://file.scirp.org/pdf/IJG_2013123115125481.pdf

Fang Wei (2019).Regional Stability Analysis of Red Clay Slope Based on Different Failure Modes: A Case Study in Taizaifu Area, Fukuoka. Advances in Civil Engineering. Research Article. V 19 PP 1-11. Article ID 1269832.

Pandey V K \& Tiwari N K (2021). 'Angle of Repose and Slope Stabilization in Himalaya'. International Research Journal of Modernization in Engineering Technology \& Science. Volume 3 Issue 9. Pg 169178. e-ISSN: $2582-5208$

Pandey V. K. (2018). Geological and Geotechnical Challenges In Road Widening, National Highway44:- Jammu-Udhampur-Banihal- Qazigund, J\&K, India. International Research Journal of Earth Science. 6(12), 22-28, ISSN 2321-2527.

Singh Ashok K, Sarkar Kripamoy, Kundu Jagadish (2018). Stability analysis of a recurring soil slope failure along NH-5, Himachal Himalaya, India. Natural Hazards 90(2):863-885. DOI:10.1007/s11069017-3076-z

Singh Y. (2006). Geotechnical and Structural Evaluation of Tectonostratigraphic Units along the National Highway, NH-1A between Udhampur and Batote Jammu Himalaya. Ph.D. Thesis, University of Jammu, Jammu, Unpublished.

Slope Stability Report. Four Laning of Udhampur- Ramban Section of NH-1A from km 67.00 to km 89.00, km 130.00 to $\mathrm{km} 151.00$ in the state of J and K. Submitted by Gammon India Limited to National Highway Authority of India. Oct 2016.

Verma R.S. (1966-67). Geological report on the Landslides along the Jammu-Srinagar National Highway (1A), Jammu and Kashmir State. Geological Survey of India, Northern region, Lucknow. Field Season report 1966-67. http://www.portal.gsi.gov.in/gsiDoc/pub/ NRO-JK_12925.pdf 